\title{
Planning and Financing in the Social Development
}

Submitted 21/08/19, $1^{\text {st }}$ revision 27/09/19, $2^{\text {nd }}$ revision 11/10/19, accepted 20/11/19

\author{
S.S. Galazova ${ }^{1}$
}

\begin{abstract}
:
Purpose: Determining the purpose, content, appropriation, features of the program-target and design-target methods of planning and financing in the social sphere and the ways of their further development.

Design/Methodology /Approach: In modern conditions of economic and financial uncertainty in the social sphere, reform changes, aimed at improving the quality of public finance management are in progress. These transformations were launched by the Ministry of Finance of Russia in 2004, when the main directions of budget sector reform were identified, including the transition to new forms of financial support for the provision of state (municipal) services, the introduction of result-oriented budgeting methods. The presented article is devoted to the methods of a programmatic approach to planning and financing in the social sphere development.

Findings: An integrated approach to the implementation of planning, financing and management of budgetary resources in the social sphere will make it possible to consider the program-target and project-target methods as the key tools for the distribution of labor, material and financial resources to achieve the goals and objectives, while the levels of goals achievement must have measurable indexes (indicators) that have the ability to influence the managed object.

Practical implications: The results of the study can be applied in the management activities of the state and municipal authorities, social institutions with the aim of developing the program-targeted and design-targeted methods of planning and financing.

Originality /value: The main idea of the modern stage in the development of program methods for planning and financing in the social sphere is that a new quality of public and municipal finance management, optimization of budget expenditures requires the inclusion in the state programs of measures aimed at achieving the goals stated in the relevant national and federal projects
\end{abstract}

Keywords: Social sphere, program approach, program-target method, project-target method.

JEL Codes: H61, H69, H79

Paper type: Commentary note: Social Development.

\footnotetext{
${ }^{1}$ Professor, North Ossetian State University named after K.L. Khetagurov, Vladikavkaz, Russian Federation, e-mail: nosu@nosu.ru
} 


\section{Introduction}

The constitutional definition of Russia as a market-oriented socially oriented state is required to consider the issues of improving the quality of social finance management as a key issue. The fundamental role of personal qualities, knowledge, abilities, skills, competencies, opportunities for professional development today gives an important place to the social sphere in modern society of a new digital type. The transformation of knowledge into fixed capital in the conditions of the information technology society has significantly strengthened the importance of such social sectors as education, healthcare and culture.

In recent decades, the role of the main branches of the social sphere in the world has changed, which is confirmed by the concepts of socio-economic development of many states, in which the theory of human capital and the social capital quality improving plays a special role. It is the human capital that becomes the most important resource for the innovative type economy's development and is crucial for ensuring national competitiveness. Strengthening the role and the importance of human capital in ensuring the economy's development determines the need for growth in the volume of financial resources allocated by the state and the society to meet the needs of the social sphere's main sectors and their further development.

\section{Materials and Methods}

The objective need for the development of planning methods is especially relevant in the current conditions of economic uncertainty, which require stable and sustainable financial support for the social sphere, timely fulfillment of the state's constitutional obligations in this direction. It should be noted that market transformations and ongoing budget reform measures implemented in the country were aimed at solving these problems.

Table 1. The Russian Federation state extra-budgetary funds consolidated budget and budgets expenses growth trend for the social sphere in 2013-2018

\begin{tabular}{|l|l|l|l|l|l|l|}
\hline Costs & 2013 & 2014 & 2015 & 2016 & 2017 & 2018 \\
\hline Social costs in total, including & 14200,5 & 15036,9 & 17025,8 & 17826,8 & 18927,5 & 19842,4 \\
\hline -education & 2888,8 & 3037,3 & 3034,6 & 3103,1 & 3264,2 & 3668,6 \\
\hline -culture, cinematography & 377,0 & 410,0 & 395,6 & 422,8 & 492,9 & 528,2 \\
\hline -healthcare & 2318,0 & 2532,7 & 2861,0 & 3124,4 & 2820,9 & 3315,9 \\
\hline -socialpolitics & 8397,4 & 8803,3 & 10479,7 & 10914,2 & 12022,5 & 11998,2 \\
\hline -physicalcultureandsport & 219,3 & 253,6 & 254,9 & 262,3 & 327,0 & 331,5 \\
\hline
\end{tabular}

The data presented in table 1 show that in the period of 2013-2018 there has been a steady upward trend in the social expenditures of the consolidated budget of the Russian Federation and the budgets of state extra-budgetary funds over the past years (Table 1). 
During the period under review, the absolute amount of the consolidated budget expenditures in the Russian Federation for the social sphere increased from 14,200.5 billion rubles. to 19842.4 that is, $39.72 \%$. Such a significant increase in the social expenditures of consolidated budgets had an impact on medical and demographic trends.

Figure 1. Dynamics of indicators of population movement and life expectancy in the Russian Federation in 2013-2018. ${ }^{2}$

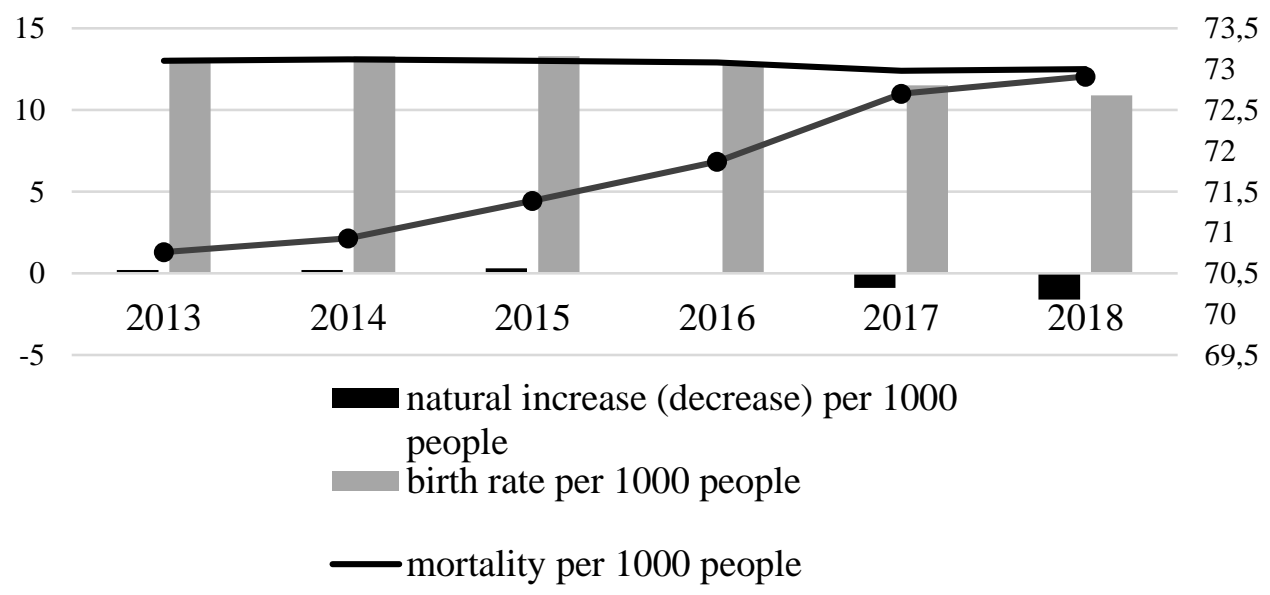

Significant expenditures made it possible to improve Russia's social development indicators and achieve the planned strategic goals outlined in state programs, which allows to speak about the new quality of managing state and municipal finances and the development of financial planning and financing methods in the social sphere, including the program method.

The main indicators of the natural movement of the population and life expectancy in Russia have changed. Thus, there has been a steady decrease in the mortality rate from 14.5 in 2013 to 13.6 in 2018, an increase in life expectancy from 75.13 years to 76.93 during the period under review. Significant government spending allowed to improve the overall social indicators of Russia's development and achieve the planned strategic goals outlined in state programs, which made it possible to speak about the new quality of managing state and municipal finances and the development of financial methods of planning and financing in the social sphere, including program approach.

Program approaches and their tools began to be actively implemented into the planning and financing of the social sphere from the moment of the reforming the budget process concept in the Russian Federation in 2004-2006 introduction, in

${ }^{2}$ Compiled by the author basing on GKS, 2019 
accordance with which, the main direction of the public finance management process transformation was determined as the transition to program methods of budget planning and financing.

So, at a joint meeting of the board of the Ministry of Finance of Russia and the Ministry of Economic Development of Russia (05/14/2010), a directive to radical changes in the organization of state management of financial resources was given and the transition to a new, program-targeted budget structure, suggesting that the basis of the Russian Government Federations activities will be laid state programs has been set. As a part of the Program for Improving the Efficiency of Budget Expenditures implementation for the period until 2012, a transition to the program classification of budget expenditures, the structure of which was determined by the goals of the state socio-economic policy and the tasks of developing the social sphere, has started. These changes made it possible to link the functional activities of executive bodies of all the levels with social priorities recorded in the program documents, which in turn provided the result-oriented budgeting introduction and development.

In this regard, all the subsequent stages of budgeting in the social sphere were focused not on the medium-term planning and financing development, but on the predominant use of a program approach, including program-target and project-target methods.

\section{Results}

The accumulated experience in applying the program approach to planning and financing expenses of the main branches in the social sphere, which were based on state social programs, demonstrated not only its advantages, but also stipulated the transition to the new program-oriented and design-targeted methods' introduction. This is confirmed by the intense attention of the researchers who actively discuss such issues as content, essential and distinctive features of the program-target method, requirements for observing certain conditions of program-target planning, the advantages of the program-target method, etc. on the economic press pages.

Some authors, in our opinion, quite correctly believe that the budget planning transfer to program-targeted methods, including the social sphere, requires the following conditions to be met:

- the establishment and delimitation of responsibility centers by ensuring the implementation of a single program and related projects by structural units of the same budget manager;

- the need for grouping projects depending on the program objectives, but regardless of the funding source;

- $\quad$ subsidization of business entities targeted and quantifiable by performance indicators (Beskorovaynaya, 2011).

The authors' position according to which among the signs allowing to distinguish the 
program-target method from, for example, budget planning, budget forecasting and budgeting, the following positions are distinguished:

- focus on eliminating social problems;

- the existence of a goal-setting system that meets the specified priorities for the social sphere development and the state bodies responsibilities;

- the presence of interrelated activities, the implementation of which leads to the planned goals achievement and the social problems elimination;

- the presence of targets (indicators) characterizing the degree of goals achievement, objectives and activities;

- determination of the necessary volumes of financial resources for the implementation of activities on time seems to be the most justified (Pinchuk, 2018).

The essential features noted above are also characteristic of the project-targeted approach, which allows them to be considered as tools of a program approach to planning and financing in the social sphere.

Figure 1. The content of the methods of program-targeted and design-targeted approaches in the social sphere

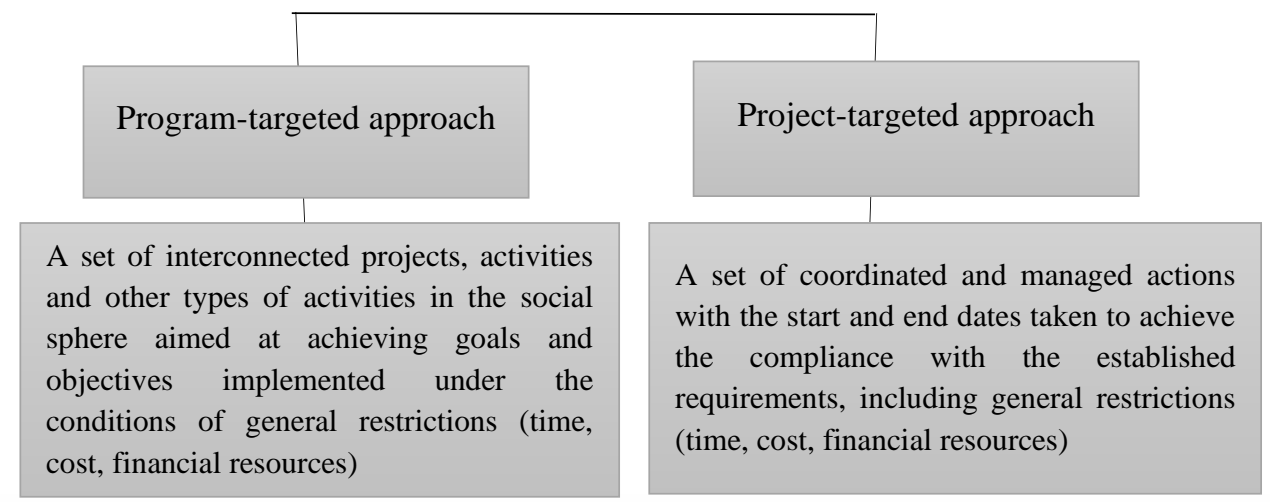

We agree with the point of view of a number of authors who believe that the two considered methods of planning and financing social expenditures have both common and distinctive features: a common element is the orientation toward achieving the target results, as for the distinctive features - this is the scale and purpose (Pererva et al., 2016; Kozlov, 2011; Denisova et al., 2017). Due to this position, for example, the project-targeted approach to the implementation of the Russian education development program ensures the goals achievement and the planned indicators of the state education development program using a set of integrated projects.

A comparative description of the program-targeted and project-targeted approaches to planning and financing shows the features of their goals, indicators and activities. So, the features of the goals and indicators of the program-target method are the 
presence, as a rule, of a "target tree"; in terms of content, they are the missions admitting their qualitative formulations and not having a clear numerical expression; as well as the availability of qualitative and quantitative indicators.

Regarding the project-target approach, the goals' formulation must meet the following criteria: specificity, measurability, attainability, relevance and limited time; high level of quantitative certainty in the initial setting of goals. The indicators are mainly quantitative. The features of the program-target approach activities, as a rule, include maintaining consistency with goals over time, with planned budgetary and other sources, and the design-target approach also includes consistency with goals over time, with planned budget and other sources; focus on changes in the current system and obtaining the expected results, implementation in conditions of high risks, economic and financial uncertainty (Pinchuk, 2018; Polyakova et al., 2019; RupeikaApoga et al., 2019).

So, for example, the federal target program for the development of education for 20162020, which provided for a project-targeted approach to planning and financing in the education sector for the specified period in the framework of the state program "Development of education" for 2013-2020 had already been adopted.

\section{Discussion}

In June 2016, the President of Russia signed a decree "On the Council under the President of the Russian Federation for Strategic Development and Priority Projects" (from July 19, 2018, the Council was transformed into the Council under the President of the Russian Federation on Strategic Development and National Projects), according to which a transition was envisaged to project management, as well as its combination with the ongoing activities of ministries and departments (Decree, 2018a).

The decree formed the approaches to the formation of priority projects, among which were named: determining the circle of the most important issues requiring the use of the project principle when deciding; informing the public about the importance of projects, both for the national economy and for improving the standard of living of people, designation and linking of short-term and long-term goals (Decree, 2018b).

By the Government of the Russian Federation order dated January 31, 2019 No. 117 $r$ "On Approving the Concept for Improving the Efficiency of Budget Expenditures in 2019-2024", the directions for improving the system of state programs and implementing the principles of project management were identified (Order, 2019).

The programs "Development of education" for 2018-2025, "Development of health care" for 2018-2024, and "Development of culture" for 2013-2024 and other projects were identified as pilot government programs for transferring to the project management mechanisms in the social sector from 2018. 
During the implementation of priority national projects approved in accordance with the Decree of the President of Russia V.V. Putin from 05/07/2018 "On national goals and strategic objectives of the development of the Russian Federation for the period until 2024", the state programs are becoming an effective tool for the economic entities design and functional activities implementation in the social sphere, testifying to the invested financial resources and the results obtained (Decree, 2018c). In the social sphere, the following national projects are being implemented: "Healthcare", "Education", "Science", "Culture".

For example, the national project "Education" implementation provides the achievement of the following goals: ensuring the global competitiveness of Russian education; the Russian Federation is one of the 10 leading countries in the world in terms of the general education quality, as well as the upbringing a harmoniously developed and socially responsible person.

It is planned to allocate 784.5 billion rubles for the financial support of the national Education project activities within 6 years, including 723.3 billion rubles from the federal budget. In the framework of the national project, the bulk of funding falls on the following federal projects: "Modern School" - 295.1 billion rubles, which is $37.61 \%$ of the total funding; "Young Professionals (Improving the Competitiveness of Vocational Education)" - 156.2 billion rubles -19.89\%; "Education Export" - 107.5 billion rubles $-13.64 \%$; "Digital educational environment" - 79.8 billion rubles $10.17 \%$ and "Success of every child" - 80.5 billion rubles - 10.26\% (NP Education, 2018).

\section{Conclusion}

Improving the social development indicators of Russia, achieving the planned strategic goals and objectives outlined in state programs, made it possible to draw a conclusion about the new quality of managing state and municipal finances and the development of financial methods of planning and financing in the social sphere, including the program method.

It seems that the main idea of the modern stage of the program methods development in the social sphere is that in order to improve planning, optimize the budget expenditures, the government programs should include the activities aimed at achieving the goals stated in the relevant national and federal projects (Budget, 2018).

The complex nature of planning, financing and managing budgetary resources in the social sphere will make it possible to reasonably consider the program-target and project-target methods as key tools for the distribution of labor, material and financial resources to achieve goals, while levels of achievement of goals have measurable indexes (indicators) with the ability to influence the managed object. 


\section{References:}

Beskorovaynaya, S.A. 2011. The modern stage of budget reform in the Russian Federation. Accounting in non-profit organizations, 3(267).

Budget. 2018. Toward a digital economy through improving the budget process. Available online: http://bujet.ru/article/355404.php.

Decree. 2018a. Decree of the President of the Russian Federation of July 19 No. 444 "On streamlining the activities of consultative and advisory bodies under the President of the Russian Federation" (together with the "Regulation on the Council under the President of the Russian Federation on Strategic Development and National Projects"). Available online: http: //www.garant.ru.

Decree. 2018b. Decree of the Government of the Russian Federation of October 31 No. 1288 "On the organization of project activities in the Government of the Russian Federation" (together with the "Regulation on the organization of project activities in the Government of the Russian Federation"). Available online: http: //www.garant.ru.

Decree. 2018c. Decree of the President of Russia V.V. Putin of 05.07 "On national goals and strategic objectives of the development of the Russian Federation for the period until 2024". Available online: http: //www.garant.ru.

Denisova, P.I., Rukina, N.S., Samoylova, N.K., Takmazyan, S.A. 2017. Financial Instruments of the Socially Responsible Economy. European Research Studies Journal, 20(1), 284-293.

Kozlov, A.S. 2011. Methodology of program and project management. Moscow, Flinta Publishing House, 194.

NP Education. 2018. The passport of the national project "Education". Approved by the Presidium of the Presidential Council for Strategic Development and National Projects, available online: http: //government.ru/.

Order. 2019. Order of the Government of the Russian Federation dated January 31 No. 117-r "On approval of the Concept of increasing the efficiency of budget expenditures in 2019-2024”. Available online: http: //www.garant.ru.

Pererva, A.D., Eranov, S.V., Sergeev, S.N. 2016. Way of IT-manager. Management of the project environment and IT projects. St. Petersburg, Peter, 320.

Pinchuk, A.V. 2018. Project method: concept and role in the system of planning budget expenditures. Economics, taxes, law, 4(11).

Polyakova, A.G., Loginov, M.P., Serebrennikova, A.I., Thalassinos, E.I. 2019. Design of a socio-economic processes monitoring system based on network analysis and big data. International Journal of Economics and Business Administration, 7(1), 130-139.

Rupeika-Apoga, R., Romanova, I., Bule, L., Thalassinos, E.Y. 2019. The Impact of Population Ageing and Social Stratification: The Case of Latvia. International Journal of Economics and Business Administration, 7(1), 49-63. 